\title{
The Meeting Point of Neo-Sufism and School Counselors Competencies
}

\author{
(Titik Temu Karakter Neo-Sufisme dengan Kompetensi Konselor Sekolah)
}

\author{
R. Ridwan ${ }^{1 *}$, Anwar Sutoyo ${ }^{2}$, Ali Mansur ${ }^{3}$ \\ ${ }^{1}$ Department of Guidance and Counseling, Faculty of Education, Universitas Hamzanwadi, \\ Cut Nyak Dien Street No. 85, Lombok Timur, West Nusa Tenggara, 83611 Indonesia \\ ${ }^{2}$ Department of Guidance and Counseling, Faculty of Education, Universitas Negeri Semarang, \\ Kampus Timur Street, Semarang, Central Java, 50229 Indonesia \\ ${ }^{3}$ State Senior High School 1 Sikur, Raya Paok Motong Street, Lombok Timur, West Nusa Tenggara, 83662 Indonesia \\ *corresponding author, e-mail: ridwan0761@gmail.com
}

Article received: April 11 ${ }^{\text {th }} 2020$; revised: August 19 ${ }^{\text {th }} 2020$; accepted: August $21^{\text {st }} 2020$

\begin{abstract}
Neo-sufism is the recent Sufi movement that actively develops society. Historically, sufism has brought forth arif billâh individuals who have great faith and devotion to Allah, excellent pedagogical competence, as well as social and professional skills. This study aims to construct the meeting point between neo-sufism character and school counselor competence. It was carried out using a qualitative approach with the Hermeneutic analysis from Paul Ricoeur. The data was obtained from documents and interviews. The results reveal the meeting point between neo-sufism character and four counselors competencies. Makrifatullah (depth comprehension of God) character is linear with pedagogical and personality competence. Prioritizing other people (itsar) and noble (futuwwah) character are in line with social competence; meanwhile, creative-productive (intajiyyah) character is in accordance with professional competence. Therefore, neo-sufism character transforms counselors' competencies to be more significant and meaningful.
\end{abstract}

Keywords: neo-sufism; counselor competence; knowledgeable; recuper

\begin{abstract}
Abstrak: Neo-sufisme adalah sebuah gerakan sufi baru yang aktif membangun masyarakat. Dalam sejarahnya, sufisme telah melahirkan pribadi arif billâh, yang arif-bijaksana karena Allah, yang atas nama Allah mampu sebagai penyembuh. Sementara itu, salah satu kompetensi kepribadian konselor adalah beriman dan bertakwa kepada Tuhan, di samping kompetensi pedagogik, sosial dan profesional. Tujuan artikel ini adalah mengkonstruksi titik-temu karakter neo-sufisme dengan kompetensi konselor sekolah. Penelitian ini dilakukan dengan menggunakan pendekatan kualitatif, melalui penggunaan analisis hermeneutika dari Paul Ricouer. Data dikumpulkan dari dokumen dan wawancara kasus. Hasil menunjukkan bahwa terdapat titik-temu karakter neo-sufisme dengan empat kompetensi konselor. Karakter makrifatullah bertemu dengan kompetensi pedagogik, dan kompetensi kepribadian. Sementara itu, karakter sangat mementingkan orang lain (itsar) dan karakter kesatria (futuwwah) bertemu dengan kompetensi sosial, karakter kreatif-produktif (intajiyyah) bertemu dengan kompetensi profesional. Dengan karakter neo-sufisme, kompetensi konselor akan menjadi lebih baik dan lebih bermakna.
\end{abstract}

Kata kunci: neo-sufisme; kompetensi konselor; arif; penyembuhan 


\section{INTRODUCTION}

Since the 1980s, the guidance and counseling results remain on the surface (Ridwan, 2019; Sutoyo, 2017). The experts and practitioners have recommended the inclusion of religious teaching into counseling practices to solve that issue (Mappiare-AT, 2018). Consequently, since the 1990s, the integration of religious spirituality and the therapeutic (clinical) framework has resulted in the tremendous interest as competencies required to solve the counselee diversity (Parker, 2011). The recent contribution to that discussion has been reported by Ahmed \& Amer (2012) and Rassool (2015). Besides, Muslim counseling practitioners have also acknowledged that spirituality has become a contributing factor toward psychological health sustenance since both medical, spiritual and counseling generally have the same purposes (Bakar, 2016; Damari, Hajebi, Bolhari, \& Heidari, 2018; Rassool, 2015; Sabiq, 2016). Therefore, the spiritual dimension is an integral part of the counseling that aids individuals resolve their problems (Ridwan, 2019).

As a country with a religious-cultural background, in 2008, Indonesia's National Education Ministry has positioned personality competence with great faith and devotion to Allah as the primary competence. Spiritual competence marks a counselor with an exceptional personality (Kushendar \& Fitri, 2018). Counselors with religious personalities can help various counselees, primarily in the Islam socialreligious context (Rassool, 2015). In addition to personality competence, counselors are also demanded to master pedagogical, social, and professional competencies (Departemen Pendidikan Nasional, 2008).

Guidance and counseling is a helping profession (Cormier, 2017) in solving problems, adjusting behavior (Erford, 2017; Smith-Adcock \& Tucker, 2016) or healing (Damari et al., 2018; Farshadnia, Memaryan, Farid, \& Bolhari, 2018) and bringing human prosperity (Ardimen, 2018). The adjustment of behavior or recuperation is eminently related to the personality of the counselor, helping them. The counselor personalities are divided into two. The first is compelling counselor personalities based on the western theoretical formulation, which might be irrelevant to the Indonesian socio-psychic condition. Second, the counselor personality standards tend to be top-down, following government regulation, not bottom-up from each counselor (Mappiare-AT, 2013). Thus, counselors' roles are less optimal in helping counselees (Hariko \& Ifdil, 2017). Counselors' personalities even have not matched the personal characteristics of spiritual figures who can reform or rehabilitate someone's behavior. As the consequence, an approach that connect counselors competencies and the desired personal quality as a healer is required.

In the Islam context, the ability to help is inseparable from Allah's blessing for those giving help. Allah grants the prayers of those with a genuine heart to heal (Frager, 2014). As Allah's messenger, Prophet Muhammad PBUH is the primary example in the alteration and healing, known as ath-Thibbun Nawabiy (Ridwan, 2018a). It was maintained by the companions of Prophet Muhammad PBUH, tabi' in (the followers of those companions, such as Imam Hasan Bashri), and tabi'it tabi' in (the followers of tabi'in, such as Ibnul Jauzi). Meanwhile, Imam al-Ghazali, greatly known as the pioneer of modern sufism, was popular for his recuperation using spiritual counseling; similar to Ibnu Qayyim al-Jauziyyah, the pioneer of neo-sufism, who introduced internal monologue or internal dialogue, which was used to restructured cognitive linear into cognitive behavioral therapy (Rassool, 2015). Earlier than Imam al-Ghazali and al-Jauziyah, Abu Bakar ar-Razi was a doctor, physicist, philosopher, and distinguished counselor for depression treatment (Ridwan, 2018a). Recently, this sufy-like method has been continuously developed, from the treatment for narcotics addiction to the inner peace attainment (Bassar, 2018). Thus, many Muslim psychologists integrate this sufism concept into western psychotherapy models (Naufal Istikhari, 2016). This concept is introduced in Islamic guidance and counseling as sufism counseling (Mubasyaroh, 2017; Rahman, 2017; Sutoyo, 2017) or neo-sufism counseling (Ridwan, 2017, 2019, 2018b).

Sufism is a doctrine to achieve Islam's three pillars, namely good deeds (ihsan), faith and Islam (Munirah, 2019; Ridwan, 2014a). The concept of ihsan comes from Prophet Muhammad's PBUH hadith "when Gabriele asked, "Tell me the concept of ihsan!", and Prophet Muhammad PBUH answer "That you worship Allah as if you see Him, and when you could not see Him, He sees you" (HR. Muslim, Abu Dawud dan at-Tirmidzi, in Nasir, 2019; Usman, 2019). This hadith implies that sufi experiences as if he 
sees God or feels His presence. By sensing God's presence, someone's faith gets stronger, resulting in a greater moral force to carry out good deeds (Sabiq, 2016).

A believer might be sufi once he enables his heart potential (Frager, 2014; Ridwan, 2014b) to enter the realm of the spirit. Western psychology ends at the soul and unable to access the more transcendental dimension (Frager, 2014). Victor Frankl, the pioneer of Logotherapy, states that noetic is associated with the meaning of life (Istikhari, 2016). Thus, noetic psychotherapy emerges (Costello, 2015). Noetic represents the third realm, after the 'alam Nâsût (physical realm) and Malakût (the first metaphysical realm seen by metapsychic). Above the noetic (Jabarût) realm, the Tanazzulat ('alam Sirr, or the middle realm), Lâhut or the world of Godness (the realm identified as God manifestation place) dan Hâhut (the realm that is not approachable by space and time). If a believer can get into Malakût realm, then he can feel God's presence (Ridwan, 2018a) and the meaning of life. Consequently, once counselors can sense God's presence, their healing prayer will be granted by God easily. Those counselors can depict them as a figure who can transform their words into prayers (Mappiare-AT, 2018).

The benefits discussed in the above paragraphs brought by sufism. It is a discipline that observes the goodness and badness in one's soul, rinse it, and decorate it with commendable moral to be closer to God (Muchasan, 2018; Ridwan, 2018a). Therefore, classical Sufi swamped in the prayer and carry out a complete 'uzlah (self-isolation) and zuhd (detachment) (Nasir, 2019; Rostitawati, 2018), so that neglecting the social activities. Currently, neo-sufism has undergone a number of corrections to adapt to the recent era (Nasir, 2019).

In addition, neo-sufism emerges as a reaction toward the exaggerating belief toward modern science and technology (Aziz, 2013). Modernism is perceived to be failed to offer meaningful life so that most people get back to religions (Nasir, 2019; Usman, 2019). Besides, people also practice sufism to facilitate their spiritual healing (Aziz, 2013; Sutoyo, 2015; Zein, 2015). The rise of neo-sufism is focused on Muslim society's socio-moral observation and development (Muchasan, 2018; Nasir, 2019; Rostitawati, 2018).

Therefore, neo-sufism is presumed to be relevant and empowering professional advancement (Ridwan, 2018a). It carries a great spirit of devotion. The neo-sufism movement consists of several acts. First, resisting the extreme and ecstatic sufism practice while simplifying it following the sharia (Rostitawati, 2018) by maintaining the spiritual soul purity (Nasir, 2019). Second, rejecting the exaggerating veneration toward Sufi Wali Sanga (friend of God) (Rostitawati, 2018). However, this movement still perceives learning as an essential part (Nasir, 2019). Third, the willingness to join politics and heroic-patriotism to defend Islam (Rostitawati, 2018). Thus, 'uzlah is completed when required (Nasir, 2019), while zuhd is translated into not getting overpowered by the world while controlling the world. Even with those aspects, experts have not acknowledged considerable differences between classical sufism and neo-sufism (Nasir, 2019). The difference only lays in the modern sufism that emphasizes the balance between the world and after-life importance (Sutoyo, 2015). This movement brings the ability to transform someone into God's caliph in this world (Al-Qur'an 2:30), who present the best performance in their proffesion.

Sufism's initial primary product is the emergence of 'arif billâh individual, Sufi Sheikh (Mursyid or teacher) or perfect human being (Ridwan, 2017, 2019, 2014b) who deeply understand God through his eyes of the heart. Someone can be 'arif billâh (perfect human being) once he enables his heart potentials to get into the Tanazzulât, and Lâhût realm or the world of Godness, the realm attained by Prophet Muhammad PBUH during his ascension (Istikhari, 2016). The knowledge of an 'arif is known as makrifatullah (depth comprehension of God). An 'arif billah is different from the common wise man since God directly instructs his virtues; meanwhile, the ordinary wise person is only guided by the environment (Ridwan, 2014a). Muslim counselors can obtain makrifatullah on the mind to heart level to feel God's presence (Ridwan, 2014a) in the Jabarût realm (neotic realm, according to Frankl).

In short, the essential product of neo-sufism is a wise character, based on makrifatullah. In completing their professional task, Muslim counselors can discern the mind to heart level once they are religious. Religion is the life totality since essentially religion had existed since the human was created. The existence of religion is inseparable from counselors' lives (Siregar, 2019). This study aims to construct the meeting point of neo-sufism and school counselor competencies. It is expected to bring a professionally-wise counselor model. 


\section{METHOD}

This research uses a qualitative approach with hermeneutics from Ricoeur. The hermeneutic analysis was completed through some stages. First, the semantic stage was carried out by reading documents and comprehending the identified data. Second, the reflective phase was completed by grouping the data into the focused aspects. Lastly, the existence stage, conducted through interpreting the data meaning based on the obtained information. This stage was put as the fundamental of design model planning.

The primary analyzed document is a dissertation on the neo-sufism foundation to establish wise behavior (Ridwan, 2014a; Departemen Pendidikan Nasional, 2008). Meanwhile, the textual data analyzed were texts on wise individual behavior, on the mind-to-heart level, four primary competencies, and the proponent competencies required for school counselors. This document study aims to construct the meeting point conceptually. Simultaneously, the interview was carried out with the school counselor. The purpose of that interview was to discover the meeting point of those characters with school counselor performance, which was used as the model planning material.

The qualitative data analysis was completed simultaneously with: (1) data reduction, consisting of selecting, focusing, and simplifying the data, (2) data presentation, which included organizing the data by arranging the information from the reduction results, (3) data verification, completed through testing the correctness and compatibility between the data significance. The interview data analysis was conducted by assigning $\mathrm{W}$ code chronologically. The data validation was carried out using data triangulation and experts examination (Moleong, 2010), and peer review. The initial product planning of the wise counselor model was formulated after the construction of the meeting point.

\section{RESULTS}

Essentially, the terms of character and competencies are not equal. According to Indonesia Laws no. 14 , the year 2005, competence refers to a set of knowledge, skills, and behavior required to be possessed, comprehended, and mastered by teacher or lecturer in completing their professional tasks (Undang-undang Republik Indonesia nomor 14 tahun 2005 tentang Guru dan Dosen, 2005). In contrast, the character is linear to morals in Islam (Ridwan, 2017). According to Ibn Miskawaih, a Muslim philosopher with many works on investigating and discovering characters or morals issues, morals are a soul state that encourages someone to complete an action without a thorough consideration (Siregar, 2018). The comprehended and mastered values are converted into someone's conscience and turn into their character. Meanwhile, Carl Rogers explains that the competencies that have become counselors' character and demonstrated during the counseling involve congruence, sincerity, unconditional attention, and empathy (Rassool, 2015). Therefore, the purpose to construct the meeting point of character and competencies can be obtained.

The text analysis on an 'arif billâh character carried out by Ridwan (2014a), was started by analyzing the term makrifatullah introduced by classical sufi, from Dzun Nun al-Mishri to Ibnu Qayyim al-Jauziyah, as the pioneer of neo-sufism. The results of that analysis reveal four main characters, namely makrifatullah, itsâr (highly prioritizing other people), futuwwah (noble person), and intajiyyah (creative-productive). Details of each character were composed in the form of indicators. Those four main characters of an 'arif billah can be completely attained through the use of heart empowerment. Besides, a study conducted by Ridwan (2014a) toward students lowers the makrifatullah level, from the heart-pure to the lower makrifatullah level of mind-to-heart. In other words, everyone can be a wise person without being an 'arif billâh. Below that mind-to-heart level is mind level, and the lowest level is physical.

According to Ridwan (2014a), four primary characters of 'arif billah are linear with other research findings, such as a study on wellness (Myers, Sweeney, \& Witmer, 2000; Witmer \& Sweeney, 1992); and khûdi concept from Muhammad Iqbal. Those characters include relation with God, another human being, nature, and other socio-cultural businesses, including life as a country's resident (Usman, 2019). The indicators of those four mind-to-heart wiseness levels are presented in Table 1.

In addition, the legal basis of counselor competencies is the Ministry of NationalEducation and Culture Regulation No. 27, the year 2008. This regulation is the highest legal basis of counselor competencies that remains to be implemented (Kementerian Pendidikan dan Kebudayaan, 2016). It explains four 
Table 1. The Meeting Point of Neo-Sufism and School Counselor Competencies

\begin{tabular}{|c|c|}
\hline School Counselor Primary Competencies*) & Mind-to-Heart Level of Wiseness Character \\
\hline $\begin{array}{l}\text { Pedagogical Competence } \\
\text { - Master the educational theories and practices } \\
\text { - Apply the development of counselee's } \\
\text { physiological, psychological, and behavioral } \\
\text { Master the counseling service essence in an } \\
\text { educational path, type, and level }\end{array}$ & $\begin{array}{l}\text { Makrifatullah (feeling His presence), in which Allah: } \\
\text { - Knowing who knows everything } \\
\text { - The Truth, the only one undoubtedly genuine and } \\
\text { sound in truth }\end{array}$ \\
\hline $\begin{array}{l}\text { Personality Competence } \\
\text { - } \quad \text { Believe and pious to the One Almighty God } \\
\text { - } \text { Respect and uphold humanity, individuality, and } \\
\text { freedom to choose values. } \\
\text { - } \quad \text { Exhibit robust personal integrity and stability } \\
\text { Perform qualified performance }\end{array}$ & $\begin{array}{l}\text { Makrifatullah (feeling His presence), in which Allah: } \\
\text { - The Living, who grant life for everything } \\
\text { - The All-Seeing, who sees everything } \\
\text { - The Hearing, who listen to everything } \\
\text { - The Controlling, who grant the power } \\
\quad \text { The Free-Will, only His will that is applied }\end{array}$ \\
\hline $\begin{array}{l}\text { Social Competence } \\
\text { - Implement internal collaboration in the } \\
\text { workplace } \\
\text { - Has a role in a professional counseling and } \\
\text { guidance related organization and activities } \\
\text { - Implement collaboration between profession }\end{array}$ & $\begin{array}{l}\text { Prioritizing Other People } \\
\text { - } \quad \text { Prioritizing other people than themselves } \\
\text { necrifice for other people, by giving everything } \\
\text { needed by different people } \\
\text { Prioritize Allah blessing } \\
\text { Noble Deeds } \\
\text { - Abandon hostility, dissociate differences } \\
\text { Approaching those who are staying away from } \\
\text { them or maintaining a relation }\end{array}$ \\
\hline 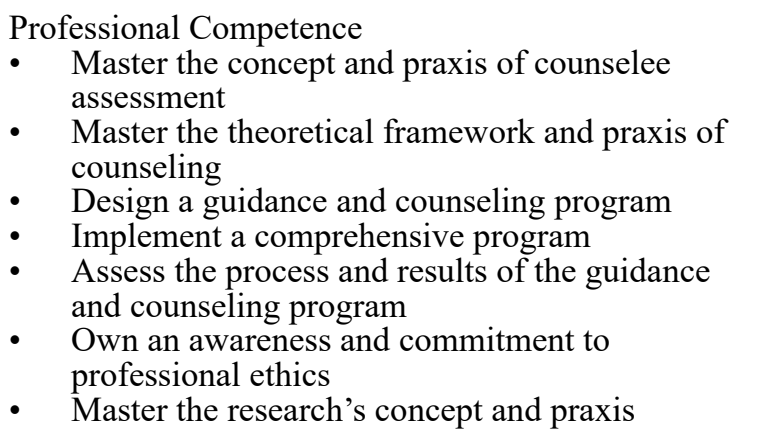 & $\begin{array}{l}\text { Creative-Productive } \\
\text { - } \quad \text { Delighted of everything being carried out } \\
\text { Being unique, doing different things compared to } \\
\text { other people } \\
\text { - } \quad \text { Being the initial practitioner of the designated } \\
\text { program } \\
\text { - Showing real and meaningful activities }\end{array}$ \\
\hline
\end{tabular}

primary competencies, namely pedagogical, personality, social, and professional competencies, with detailed supporting competencies. Subsequently, another Ministry of National Education and Culture Regulation, the year 2015 had also been enacted (Kementerian Pendidikan dan Kebudayaan, 2015). These regulations were used as the primary data since they are the most robust legal basis of counselor competencies and other related theories within the Department of National Education (Departemen Pendidikan Nasional, 2008). The meeting point identified from the hermeneutic analysis is shown in Table 1. Table 1 explains the sub-competencies found in the Ministry of National Education and Culture Regulation and seven names of Allah for the mind-to-heart wiseness (Ridwan, 2014a).

\section{DISCUSSION}

\section{The Meeting Point of Neo-Sufism Character with School Counselor Competencies}

Table 1 shows that pedagogical and personality competencies are linear with makrifatullah (feeling His presence through his character). According to neo-sufism character, pedagogical competencies are based on God as The Knowing and The Truthful. Once humans feel like they know many things, they feed and grow their own lust (Frager, 2013). Knowledge is from Allah, He bestows and takes it from everyone based on His will. Prophet Muhammad PBUH said, "Allah seizes knowledge from someone's heart, abruptly. However, He took it by killing the clerics, one by one. In the end, there will be no pious person; then people appoint ill-advice leaders. Once they were asked to solve issues, they gave advice with no philosophy. Thus, they are misguided and delude other people" (HR. Bukhari dan Muslim, from Abdullah bin "Amr bin 'Ash, in Nawawi, 2006). Therefore, the mastery of counseling and education theories and essence should be based on Allah, The Knowing, and The Truthful. 
The meeting point of personality competence is in believing and being pious to Allah. According to the neo-sufism theory, believing in the mind-to-heart level is empowered by feeling God's presence in every activity (Ridwan, 2014a). In this level, the counselors have experienced seven names of Allah, including The Living (acknowledging that all lives come from Him to enlighten the counselee's heart), The Hearing (relying on God to be skillful in listening during the counseling process), The Controlling (who gives the power for the counselor to carry out the profession), and The Knowing (every knowledge should be based on Him) (Ardimen, 2018; Ibnu, 2017). Besides, professional competence also appreciates and upholds humanity, individuality, and freedom of choice values, showing personality integrity and stability and exhibiting qualified performance according to neo-sufism. Once an individual gets closer to The Gatherer (al-Jami'), he has a more integral personality (Ibnu, 2017; Ridwan, 2014a). Someone with a noble deed has the inner attitude that encourages great acts and supports optimum professional performance (Ardimen, 2018; Siregar, 2018). If the counselors can incorporate those names of Allah, they accelerate their belief and devotion to Him.

The vital meeting point of neo-sufism is also detected in social competence. In this competence, the neo-sufism character involves collaboration, prioritizing other people, and doing noble deeds. Therefore, this individual prioritizes other people and is willing to sacrifice other people to attain God's blessing. This altruistic personality cares about other people's needs (Ardimen, 2018). Meanwhile, the noble characteristic avoids differences and adopts the character of never giving up. These two characters are highly required for professional counselors, primarily in administering the counselee's diversity.

According to the analysis carried out by Hastuti \& Marheni (2017), those four counselor competencies is the formulation from 11 pedagogical sub-competencies that consist of multicultural aspect; two out of 17 personality sub-competencies formulation and none are identified from the social and professional competencies. That is appealing since Indonesia subsists of various diversity in the tribes, ethnicity, religion, socio-economic status, age, gender, and so forth. Thus, counselors are expected to possess competencies related to multicultural issues. The expected multicultural sub-competence is that the counselor develops awareness and susceptibility toward cultural differences and respects the different perspectives (Hastuti \& Marheni, 2017; Riswanto, Mappiare-AT, \& Irtadji, 2017).

In neo-sufism character, counselors are not only demanded to be aware, sensitive, and respectful, but they have also to pray that God forgives the counselees and for the counselees to get God's blessing (Mappiare-AT, 2018; Ridwan, 2018a). Meanwhile, counselor competencies in Bhineka Tunggal Ika indicate a strong wish to acknowledge and preserve unity to maintain diversity (Tobari, 2018). In neosufism character, if counselors believe in getting close to The Gatherer, they accept and acknowledge (recognition principle) and preserve differences as the life reality (equality principle) with enthusiasm to compete to do good deeds, as the working enthusiasm principle (Al-Qur'an 2:148) to attain the glorious level beside God, as the devotion principle (Al-Qur'an 9:13). Therefore, neo-sufism and social competence's primary principle is to realize God caliph individuals who prosper the earth as God's apparatus to realize His will (Frager, 2013).

Professional competence covers the habit and ability to use communication, knowledge, and technical service in providing service (Sari \& Setiawan, 2018). Someone can be classified as professional if he has possessed a particular skill for a particular profession and required a fee for the service. Thus, a more experienced individual tends to request a higher payment. Additionally, teachers' and lecturer's inability to accelerate their scientific work productivity improves when they attain a research project or grant (Ridwan, 2017). They are required to carry out research and use the findings to improve guidance and counseling services (Departemen Pendidikan Nasional, 2008). Besides, the research results also show that most counselors (67\%) have not been professionally competent, while $34 \%$ of them are skilled, and only $3 \%$ of them are highly qualified (Wardhani, Farida, \& Yudha, 2019).

The neo-sufism character contributes to professionalism through creativity and productivity in generating the works. Sufi has proven that their works are timeless (Azra, 2008). Annemarie Schimmel, a sufi researcher from Germany, identifies sufi's high productivity comes from their substantial love for their work (Ridwan, 2014a).

Neo-sufism expects counselors to complete their work sincerely, shown from their happy feeling in carrying out the work. If the sufi can love their work, then the counselors can be at a lower level of loving the job, a happy feeling that boosts their creativity (Ridwan, 2014a). Consequently, it brings professionalism, including productively producing scientific works. The sufi practitioners have proven 
their attained love of God accelerates their mind once their souls are free from the desire (Ridwan, 2014a). Several products have been created from the full-of-love rational ability (Frager, 2013, 2014), in both generating a better and stronger generation, as well as the works related to science and technology. In the future, according to Mappiare-AT (2018), counselors have to picture themselves as 'magical', intelligent, creative, and productive figures.

Among the discussed competencies, personality competence is essential competence. According to Ardimen (2018), the characteristic of personality contributes $73,63 \%$ toward counselor professional performance. Other studies reveal that counselor personality is the critical factor that becomes the weight point and criteria of the service effectiveness evaluation (Sari \& Setiawan, 2018; Yusuf, 2016). A phenomenology study discovers the five themes of counselors' personality character, namely accepting the reality, finding balance, improving reflection and self-awareness, feedback transformation, as well as assimilation and integration (Coll, Johnson, Williams, \& Halloran, 2019). Meanwhile, the main norm and value of counselor personality rely on their beliefs and views of life, along with robust religious faith in God (Ridwan, 2018b; Sari \& Setiawan, 2018). Therefore, Mappiare-AT (2018) explains that counseling belongs to a socio-religious profession full of spiritual energy.

The primary meeting point is counselor awareness in believing in the One Almighty God. Further, counselors need to transform into individuals with belief and devotion to fully implement sharia by applying the third Islamic religious teaching of ihsan (good deeds) to be a genuine helper (Muchasan, 2018; Ridwan, 2014a). Consequently, counselors improve their pedagogical personality, social and professional competencies. Once they apply sufism, they come to the 'heart' of Islamic teaching (Usman, 2019). There is no perfect life with no healthy heart.

\section{The Attainment of A Case's Meeting Point}

A case obtained from the interview is discussed to explain the meeting point clearly. The interview was carried out with vocational high school counselors. The vocational school was selected due to some considerations and the compatibility with the research purposes. Its analysis results are described below, coded with $\mathrm{W}$ to ease the analysis process.

"Early in the morning, we stay at the school gate to welcome the students and note the late students. If there are dozens of late students, by the instruction of the headmaster, they are permitted to come to the school; but, if there are only one or two late students, they are instructed to go home" (W.1).

"In our school, the headmaster is directly placed as counseling coordinator" (W.2).

"After that, we have to go around the school to observe the class with no teacher and report it to the management" (W.3).

"Then, get back to the counseling room to meet three to five parents with their children in a day They come to fulfill the school invitation or by themselves. These are the parents of students with a significant number of absences or escaping the school hours, students who smoke or gamble (with money or goods) in an arm wrestle, race, and so forth" (W.4).

When they were asked about their office activity and the students' issues, they answered:

"We frequently give advice to them, then both the parents and students accept it. We also provide the statement letter signed by the students and parents that are also acknowledged by the headmaster" (W.5).

In relation to its effectivity to change students' attitude, they explained:

"Sometimes the students need three statement letters, or even four letters, which are approved by the headmaster, while the students show no changes. We have suggested a different approach, but the senior counselors explain that they have been frequently dealt with such cases. We have ever offered to drop out the students, but the headmaster rejected the idea" (W.6).

When they were asked about classical counseling or other services' schedule, they answered:

"Classical counseling has no longer existed since they are not allocated the class hour, and they have been busy giving services for parents and students in their offices. Our counseling has also no longer run since we gave too much advice" (W.7). 
Once they were asked about their personal and professional opinion on the absence of class hour, they explained:

"We really want the students to be successful in the learning process" (W.8).

"I am always confident in guiding them in my solemn worship. I frequently istighfar (praying to be protected from evil consequences and poisonous influence) but often fail to implement it consistently. I feel that I have no strong internal skills" (W.9).

The aforementioned interview summary illustrates the four primary competencies. The counselors appear to have low pedagogical competence (code W.1 to W.4) and professional competence (code W.5, W.7, and W.8). This findings are linear with the research results of Wardhani et al. (2019). Meanwhile, in social competence, the counselors have already shown the willingness to collaborate (code W.6). In personality competence, an effort to get close to Allah has appeared at one level but has not been consistent (W.9). Therefore, someone's faith and devotion level determine the serenity in completing an activity, including in dealing with the students (Rozikan \& Fitriana, 2017).

The students who often made statement letters show that guidance and counseling are incredibly related to the healing term. They made many promises and broke them (code W.6), which shows that they have not healed. According to an Islamic word, physical ill appears from the sore heart (Rozikan \& Fitriana, 2017). Thus, an individual's behavior transformed and healed due to God's guidance (AlQur'an 64:11). Meanwhile, heart pain is the material object of sufism (Istikhari, 2016; Nasir, 2019). By practicing sufism, counselors gain spiritual power to motivate the counselees to obtain God's guidance (Frager, 2014; Rassool, 2015; Ridwan, 2019).

Most counselors possibly question or have no understanding of neo-sufism (Ridwan, 2018a). Essentially, neo-sufism is based on sharia and implemented based on Islamic sharia (Nasir, 2019). If an individual diligently applies the sharia, with the teacher's guidance, his spirituality level improves and leads to the essence of life and becomes wise (Ridwan, 2014a). If someone practices sharia without sufism, he possibly commits evil deeds (Ridwan, 2018a). That wickedness is not realized only by mere rational since the rational consciousness is equal to "consciously sleeping"; they are conscious but not aware (Frager, 2014). It is due to the lack of spiritual consciousness (Ridwan, 2019). With a mere rational consciousness, many distortions are observed in Muslim counselors. Those distortions include failure to comprehend Islamic teachings, do not pray, do not fast, do not pay zakat, and do not wear Islamic clothing (Sholeh, 2018). This factor causes a decrease in counselor therapeutic ability.

\section{The Meeting Point for The Design of Wisely Professional Counselor Model}

The consideration to design the model was based on what Allah has said within the Al-Qur'an 2:208. In that verse, Allah wants Islam believers to practice Islamic teachings fully. The clerics translate the word fully into three central teachings, namely faith, Islam, and good deed, known as kaffah principles (Ridwan, 2014a). Six pillars of faith should be planted in the heart, while the five pillars of Islam need to be practiced. Meanwhile, the clerics transcribe good deeds into someone with great kindness, better treatment for others, give more than what they have received, and take less than what should be taken; the person who practices that is called muhsinin (Shihab, 2010). The ability to do good deeds is realized through Sufism teaching (Munirah, 2019). Additionally, the empirical finding wishes a wise and professional counselor model to be developed through an integrated curriculum (Herdi, Kartadinata, \& Taufiq, 2019).

As a helper profession, counselors need to be a muhsinin individual in a group of kind people (Al-Qur'an 7:56; Al-Qur'an 17:7; Al-Qur'an 29:69; Al-Qur'an 33:29). That personality is presented in the four neo-sufism characters. Those characters empower school counselors' competencies. First, personality competence is supported by feeling God's presence so that they experience no fear in completing their best performance. By practicing neo-sufism in a kaffah (thoroughly and sincerely) manner, Allah will bestow His grace. Personal integrity unites pedagogical, social, and professional competencies. Second, social competence is upheld by prioritizing recognition and equality principles (Tobari, 2018). Further, the counselors perceive diversity as wisdom (Mappiare-AT, 2018), compete to carry good deeds (Al-Qur'an 2:148) and to attain a noble position besides God (Al-Qur'an 49:13). They believe that good deeds realize God will (that all truth is only in God) and pray for forgiveness for 
their mistakes (Al-Qur'an 3:159). Third, through neo-sufism, counselors' professional competencies are developed through great creativity and productivity. The individuals who are close to God are capable of realizing themselves as God caliph, His replacement on the earth (Shihab, 2010), through offering the best services.

As for reality, many students are mentally disabled since they continuously conduct the same violations. It requires counselors' skills to enable their mind and heart potential to practice the main Islamic teachings, in ihsan sufism (Istikhari, 2016; Nasir, 2019; Usman, 2019). Dharamsi \& Maynard, (2012) mention that sufism emphasizes the process of soul development and enlightenment to cure the mind. Someone who is mentally healthy can have perfect physical activity with a healthy mind and feeling. By practicing wide sufism, counselors attain a healthy mentality (Muchasan, 2018), and lead them to cure the counselee. Thus, professional competencies are empowered to be wisely professional.

Lastly, the wise-professional counselor concept is linear with Indonesian culture. The sufism approach causes the success of Islamic teachings in Indonesia carried out by Wali Sanga (Kasdi, 2017; Kasman, 2018). That success was attained since they preached the teachings through education, institutions, and knowledge of wisdom (Kasman, 2018). Since hundreds of years ago, that success has led Indonesia to be a religious nation through the struggles of 'arif billâh figures. One of those figures is Semar, a puppet character, who is spiritual, tolerant, socially care, and so forth (Setyaputri, 2017). Therefore, this neo-sufism approach aims to strengthen the counselor competencies following the KIPAS (Counselling Intensive, Progressive, Adaptive, and Structured) counseling model from Mappiare-AT (2018), placing the guidance and counseling profession as worship and preaching activity. However, neo-sufism approach is more into teaching substantially that follows 'arif billâh.

\section{CONCLUSION}

The meeting point of counselor competencies and neo-sufism character is located in the awareness of believing in God. This counselor's spirituality is the entrance of neo-sufism. That meeting point is confirmed by acknowledging His presence in their activities. This main meeting point then strengthens social competence by prioritizing other people's needs, character and conducting good deeds, along with the development of professional competence through creative and productive personality. Additionally, with neo-sufism character, counselors become more competent in solving the issues by following 'arif billâh individuals. The needs of that character are related to the students' problems that require both solvency and cure. Thus, school counselors are suggested to understand that meeting point and prepare themselves to follow 'arif billâh individuals. That way, they improve their professionality and become wiser. To generate a model that can be implemented, a wise professional counselor model suitable with Nusantara culture should be investigated and developed. Through the neo-sufism character, counselor career and professional development can be more integrated.

\section{ACKNOWLEDGMENT}

Our most sincere gratitude is addressed toward our sufi teachers who have taught us wisdom, the lecturer and students in the guidance and counseling program who have given us great experiences, and the school counselors who have given us the meaningful experience.

\section{REFERENCES}

Ahmed, S., \& Amer, M. M. (2012). Counseling Muslims: Handbook of mental health issues and interventions. Routledge.

Ardimen, A. (2018). Visi baru konselor sekolah dalam rangka meningkatkan kualitas layanan pendidikan di sekolah dan madrasah. JKI (Jurnal Konseling Indonesia), 4(1), 22-29.

Aziz, A. A. (2013). Kebangkitan tarekat kota. Islamica: Jurnal Studi Keislaman, 8(1).

Azra, A. (2008). Ensiklopedi tasawuf. Bandung: Angkasa.

Bakar, U. A. (2016). Analisis hubungan sufisme, psikoterapi, dan kesehatan spiritual. Madania: Jurnal Kajian Keislaman, 20(2), 161-168. 
Bassar, A. (2018). Guidance and counseling of Inabah Method: Building the sufis behavior as life style in digital era. KONSELING RELIGI Jurnal Bimbingan Konseling Islam, 9(2), 70-85

Coll, D. M., Johnson, C. F., Williams, C. U., \& Halloran, M. J. (2019). Defining moment experiences of professional counselors: A phenomenological investigation. Professional Counselor, 9(2), 142-155.

Cormier, S. (2017). Strategi dan intervensi konseling bagi konselor. Translated by Annisa Nuriowandari. Jogjakarta: Published by Pustaka Pelajar.

Costello, S. J. (2015). The spirit of logotherapy. Religions, 7(1), 3.

Damari, B., Hajebi, A., Bolhari, J., \& Heidari, A. (2018). Developing a training course for spiritual counselors in health care: Evidence from Iran. Indian Journal of Palliative Care, 24(2), 145-149.

Departemen Pendidikan Nasional. (2008). Penataan pendidikan profesional konselor dan layanan bimbingan dan konseling dalam jalur pendidikan formal. Jakarta: Departemen Pendidikan Nasional.

Departemen Pendidikan Nasional. (2008). Peraturan menteri pendidikan nasional nomor 27 tahun 2008 tentang standar kualifikasi akademik dan kompetensi konselor.

Dharamsi, S., \& Maynard, A. (2012). Islamic-based interventions. In Counseling Muslims (pp. 155-180). Routledge.

Erford, B. T. (2017). Orientation to the counseling profession: Advocacy, ethics, and essential professional foundations. Pearson.

Farshadnia, E., Memaryan, N., Farid, A. A. A., \& Bolhari, J. (2018). Who can provide spiritual counseling? A qualitative study from Iran. Indian Journal of Palliative Care, 24(4), 517-525.

Frager, R. (2013). Psikologi sufi untuk transformasi hati, jiwa, dan ruh, terj. Hasmiyah Rauf. Jakarta: Zaman.

Frager, R. (2014). Sufi talk: Teachings of an American sufi sheikh: Obrolan sufi: untuk transformasi hati, jiwa, dan ruh, terj. Hikmi Akmal, Jakarta: Zaman.

Gall, J. P., \& Gall, M. D. (2003). Instructor's manual to accompany Educational research: An introduction, by Gall, Borg, and Gall. Pearson Education.

Hariko, R., \& Ifdil, I. (2017). Analisis kritik terhadap model KIPAS; Konseling intensif progresif adaptif struktur. Jurnal Konseling dan Pendidikan, 5(2), 109-117.

Hastuti, M. M. S., \& Marheni, A. K. I. (2017). Kompetensi konseling multikultur bagi konselor sekolah: Suatu kajian teoretis. in Proceeding Seminar dan Lokakarya Nasional Bimbingan dan Konseling 2017 (Vol. 1, pp. 93-109).

Herdi, H., Kartadinata, S., \& Taufiq, A. (2019). Factors affecting the wisdom of counselors: perceptions of Indonesian pre-service counselors. Jurnal Kajian Bimbingan dan Konseling, 4(4), 122-133.

Holeman, V. T. (2014). Theology for better counseling: Help from within the wesleyan-holiness theological tradition. Journal of Psychology and Theology, 42(4), 369-378.

Ibnu, A. (2017). Rahasia asmaul husna: Mengungkap 99 nama Allah.

Istikhari, N. (2016). Dilema integrasi tasawuf dan psikoterapi dalam kelanjutan islamisasi psikologi. 'Anil Islam: Jurnal Kebudayaan dan Ilmu Keislaman, 9(2), 300-327.

Kasdi, A. (2017). The role of Walisongo in developing the Islam nusantara civilization. Addin, 11(1), 1-26.

Kasman, K. (2018). Peran Walisongo dalam mentransfer tasawuf. El-Furqania: Jurnal Ushuluddin dan Ilmu-Ilmu Keislaman, 4(01).

Kementerian Pendidikan dan Kebudayaan. (2016). Panduan operasional penyelenggaraan bimbingan dan konseling sekolah menengah pertama (SMP). Jakarta.

Kementerian Pendidikan dan Kebudayaan (2015). 111 tahun 2014 tentang bimbingan dan bonseling pada pendidikan dasar dan pendidikan menengah. Jakarta: Depdikbud.

Kushendar, K., \& Fitri, H. U. (2018). The personal characteristics of an Islamic counselor in understanding identity crisis for adolescents. Islamic Guidance and Counseling Journal, 1(1), 17-24.

Mappiare-AT, A. (2013). Martabat konselor indonesia dalam falsafah dan kinerja model KIPAS: konseling intensif progresif adaptif struktur. In Prosiding Kongres XII, Konvensi Nasional XVIII ABKIN dan Seminar Internasional Konseling, Denpasar Bali (Vol. 14).

Mappiare-AT, A. (2018). Mengenal KIPAS: Model konseling berbasis budaya nusantara.

Moleong, L. J. (2010). Metodologi penelitian kualitatif. Bandung: Remaja Rosdakarya

Mubasyaroh, M. (2017). Pendekatan psikoterapi islam dan konseling sufistik dalam menangani masalah kejiwaan. KONSELING RELIGI Jurnal Bimbingan Konseling Islam, 8(1), 193-210. 
Muchasan, A. (2018). Aplikasi tasawuf pada dunia pendidikan modern. INOVATIF: Jurnal Penelitian Pendidikan, Agama dan Kebudayaan, 4(2), 1-19.

Munirah, M. (2019). Implementasi pendidikan sufisme dalam pendidikan Islam. Farabi: Journal of Ushuluddin \& Islamic Thought, 16(2), 91-104.

Myers, J. E., Sweeney, T. J., \& Witmer, J. M. (2000). The wheel of wellness counseling for wellness: A holistic model for treatment planning. Journal of Counseling \& Development, 78(3), 251-266.

Nasir, M. I. (2019). Mistisisme Islam modern. Jurnal Diskursus Islam, 7(1), 93-116.

Nawawi, I. (2006). Syarah hadits arba 'in Imam Nawawi penta'liq Syaikh 'Utsaimin. (M. Hidayah, Ed.). Yogyakarta.

Parker, S. (2011). Spirituality in counseling: A faith development perspective. Journal of Counseling \& Development, 89(1), 112-119.

Rahman, I. K. (2017). Gestalt Profetik (G-Pro) best practice pendekatan bimbingan dan konseling sufistik. KONSELING RELIGI Jurnal Bimbingan Konseling Islam, 8(1), 151-172.

Rassool, G. H. (2015). Islamic counselling: An introduction to theory and practice. Routledge.

Ridwan. (2014a). Bimbingan berlandaskan neo-sufisme untuk mengembangkan perilaku arif (suatu ikhtiar pemaduan pendekatan nomotetik dan ideografik terhadap orang arif dan mahasiswa. Universitas Pendidikan Indonesia.

Ridwan. (2017). Mendidik ala sufi: Tafsir neo-sufisme terhadap realitas pendidikan. Segare Kedaton Institute.

Ridwan. (2019). Konseling kasus. CV Alfabeta Bandung.

Ridwan, R. (2014b). Ontologi dan epistemologi kearifan dalam pengetahuan orang-orang arif dan implikasinya untuk bimbingan dan konseling. Edusentris, 1(3), 247-259.

Ridwan, R. (2018a). Pengembangan konseling dan psikoterapi komprehensif qur'ani untuk mengatasi problematika manusia. JKP (Jurnal Konseling Pendidikan), 2(1), 1-21.

Ridwan, R. (2018b). The using of self-talk techniques in neo-sufism counseling to manage teenager's inner speech. KONSELING RELIGI Jurnal Bimbingan Konseling Islam, 9(2), 27-43.

Riswanto, D., Mappiare-AT, A., \& Irtadji, M. (2017). Kompetensi multikultural konselor pada kebudayaan suku dayak kalimantan tengah. JOMSIGN: Journal of Multicultural Studies in Guidance and Counseling, 1(2), 215-226.

Rostitawati, T. (2018). Pembaharuan dalam tasawuf. Farabi: Journal of Ushuluddin \& Islamic Thought, 15(2), 67-80.

Rozikan, M., \& Fitriana, S. (2017). Penguatan konseling Islami melalui perjalanan tasawuf dalam meraih kebahagiaan individu. KONSELING RELIGI Jurnal Bimbingan Konseling Islam, 8(1), 173-192.

Sabiq, Z. (2016). Konseling sufistik: Harmonisasi psikologi dan tasawuf dalam mewujudkan kesehatan mental. 'Anil Islam: Jurnal Kebudayaan dan Ilmu Keislaman, 9(2), 328-352.

Sari, N. P., \& Setiawan, M. A. (2018). Membangun kompetensi profesionalisme konselor berwawasan Surah Al Ashr. Konselor, 7(1), 9-14.

Setyaputri, N. Y. (2017). Karakter ideal konselor multibudaya berdasarkan nilai luhur Semar. Jurnal Kajian Bimbingan dan Konseling, 2(2), 58-65. https://doi.org/http://dx.doi.org/10.17977/um001v2i22017p058

Shihab, Q. (2010). Tafsir Al-Mishbah pesan, kesan, dan keserasian Al-Qur'an. Jakarta: Penerbit Lentera Hati.

Sholeh, M. M. A. (2018). Pola penyimpangan muslim terhadap ajaran agamanya (perspektif pendidikan Islam). Al-Fikri: Jurnal Studi dan Penelitian Pendidikan Islam, 1(1), 1-21.

Siregar, A. (2018). Struktur kepribadian menurut Ibn Miskawaih dan implikasinya pada layanan konseling dan terapi Islami. Al-Irsyad: Jurnal Pendidikan dan Konseling, 8(1).

Siregar, A. (2019). Religious foundation in guidance and counseling. International Journal of Islamic Education, Research and Multiculturalism (IJIERM), 1(1), 51-62.

Smith-Adcock, S., \& Tucker, C. (2016). Counseling children and adolescents: Connecting theory, development, and diversity. SAGE Publications.

Sutoyo, A. (2013). Bimbingan dan konseling Islami (teori dan praktik). Yogyakarta: Pustaka Pelajar.

Sutoyo, A. (2017). Model bimbingan dan konseling sufistik untuk mengembangkan pribadi yang 'alim dan saleh. KONSELING RELIGI: Jurnal Bimbingan Konseling Islam, 8(1), 1-22.

Sutoyo, S. (2015). Tasawuf Hamka dan rekonstruksi spiritualitas manusia modern. ISLAMICA: Jurnal Studi Keislaman, 10(1), 108-136. 
Tobari, T. (2018). Pendekatan filosofis terhadap multikulturalisme indonesia. Risâlah, Jurnal Pendidikan dan Studi Islam, 4(2, Sept), 54-63.

Undang-undang Republik Indonesia nomor 14 tahun 2005 tentang guru dan dosen.

Usman, A. M. (2019). Revitalisasi pendidikan karakter berbasis sufiisme merespon era revolusi industri 4.0. SALIHA: Jurnal Pendidikan \& Agama Islam, 2(2), 93-106.

Wardhani, N. S., Farida, E., \& Yudha, E. S. (2019). Profil kompetensi pedagogik dan profesional guru bimbingan dan konseling SMA di Kota Bandung. Indonesian Journal of Educational Counseling, 3(2), 147-154.

Witmer, J. M., \& Sweeney, T. J. (1992). A holistic model for wellness and prevention over the life span. Journal of Counseling \& Development, 71(2), 140-148.

Yusuf, S. (2016). Konseling individual konsep dasar \& pendekatan. Bandung: Refika Aditama.

Zein, A. (2015). Makna zikir perspektif mufassir modern di Indonesia. ISLAMICA: Jurnal Studi Keislaman, 9(2), 503-527. 